IBAD Sosyal Bilimler Dergisi

IBAD Journal of Social Sciences

dergipark.org.tr/ibad

IBAD, 2022; (12): 374-396

DOI: $10.21733 /$ ibad.1023139

Özgün Araştırma / Original Article

\title{
Eşinden Şiddet Gören ve Görmeyen Çalışan Kadınların Çok Yönlü Eylemli Kişilik Özelliklerinin, Ruh Sağlığı Sürekliliklerinin ve Toplumsal Cinsiyet Rollerinin İncelenmesi
}

\section{Investigation of the Multi-Measure Agentic Personality Traits, Mental Health Continuum and Gender Roles of Working Women Who are and are Not Exposed to Spousal Violence}

\author{
Fulya Yüksel Şahin ${ }^{1^{*}}$ \\ Ebru Çanakçı ${ }^{2}$

\section{* Sorumlu yazar \\ Corresponding author}

${ }^{1}$ Prof. Dr., Yıldız Teknik Üniversitesi, Türkiye

Prof. Dr., Yildiz Technical University, Turkey,

fusahin@yildiz.edu.tr

ORCID ID https://orcid.org/0000-0003-3454-2142D

${ }^{2}$ Uzm. Psikolojik Danışman, Milli Eğitim Bakanlığı, Türkiye

National Education Ministry, Turkey,

ebrucanakcii@gmail.com

ORCID ID https://orcid.org/0000-0001-6955-0340

Makale geliş tarihi / First received : 13.11.2021

Makale kabul tarihi / Accepted : 05.01 .2022

\section{Bilgilendirme / Acknowledgement:}

1- Araştırmacıların katkı oranları eşittir. Yazarların araştırma tasarımı (birinci yazar), alanyazın taraması (ağırlıklı ikinci yazar ve birinci yazar), veri toplama (ikinci yazar), veri analizi (birinci yazar), makaleyi yazma (birinci yazar), makaleyi dergiye sunma (birinci yazar) gibi katkıları vardır.

2- Araştırma birinci yazar danışmanlığından ikinci yazarın yüksek lisans tezinden türetilmiştir. Araştırmanın bir kısmı, TURKCESS V. Uluslararası Eğitim ve Sosyal Bilimler Kongresi'nde sözlü bildiri olarak sunulmuştur.

3- Araştırmaya katılan kadınlara teşekkür ederiz.

4-Makalenin yazarları arasında çıkar çatışması bulunmamaktadır.

5- Araştırma verileri yüksek lisans tezi kapsamında 2019 yılında toplanmıştır.

6- Bu makalede araştırma ve yayın etiğine uyulmuştur. Ölçeklerin araştırmada kullanılabilmesi için ölçekleri geliştiren ve uyarlayan kişilerden e-posta yoluyla izinleri alınmıştır. Ayrıca, katılımcılardan "Bilgilendirilmiş Onay Formu” alınmış; gönüllü olarak araştırmaya katılımları sağlanmıştır.

This article was checked by Turnitin. Similarity Index 20\%

\section{Atıf bilgisi / Citation:}

Yüksel Şahin, F. \& Çanakçı, E. (2022). Eşinden şiddet gören ve görmeyen çalışan kadınların çok yönlü eylemli kişilik özelliklerinin, ruh sağlığı sürekliliklerinin ve toplumsal cinsiyet rollerinin incelenmesi. IBAD Sosyal Bilimler Dergisi, (12), 374-396. 
ÖZ

Araştırmada, çalışan kadınların eşinden gördükleri şiddetin çok yönlü eylemli kişilik, ruh sağlığı sürekliliği ve toplumsal cinsiyet rolleri düzeylerini anlamlı bir biçimde yordayıp yordamadığı incelenmiştir. Araştırmanın çalışma grubunu 695 çalışan kadın oluşturmuştur. Araştırmada gerekli verileri elde etmek için, Aile İçi Kadına Yönelik Şiddet Ölçeği, Çok Yönlü Eylemli Kişilik Ölçeği, Ruh Sağlığı Sürekliliği Ölçeği, Toplumsal Cinsiyet Rolleri Tutum Ölçeği kullanılmıştır. Araştırmada,verilerin analizi için Doğrusal Regresyon Analizi yapılmıştır. Araştırmanın sonucunda, eşinden şiddet görmenin, çalışan kadınların çok yönlü eylemli kişiliklerinin, ruh sağlığı sürekliliklerinin ve toplumsal cinsiyet rollerinin anlamlı bir yordayıcısı olduğu bulunmuştur. Araştırmanın bulguları, ilgili alan yazın ışığında tartışılmış ve öneriler sunulmuştur.

\section{Anahtar kelimeler}

Çalışan Kadın, Eş Şiddeti, Çok Yönlü Eylemli Kişilik, Ruh Sağlığ 1 Sürekliliği, Toplumsal Cinsiyet Rolleri.

\section{ABSTRACT}

This study analyses whether spousal violence significantly predict levels of multi-measure agentic personality, mental health continuum and gender roles for working women. The study group consists of 695 working women. The " Scale of Domestic Violence Against Women", "MultiMeasure Agentic Personality Scale", "Mental Health Continuum Scale," and "Gender Role Attitudes Scale" were employed to obtain the required study data. Linear Regression analysis was performed. The results of the study showed that the spousal violence variable is a significant predictor of multi-measure agentic personality, mental health continuum and gender roles of working women. The study results are discussed in the light of the literature and certain suggestions are made.

\section{Keywords}

Working Women, Spousal Violence, Multi-Measure Agentic Personality, Mental Health Continuum, Gender Roles. 


\section{GİRiş}

Şiddet, insanlık tarihi kadar eski olan, günümüzde de devam eden, tüm toplumlarda yaygın olan (Fromm, 1994) ve aşılması oldukça güç görülen ortak bir sorundur (Dişsiz ve Hotun Şahin, 2008). "Öfkenin saldırganlık şeklinde eyleme dönüşmesi”, şiddete yol açar (Akkaş ve Uyanık, 2016; Doksat, 2011). İncitmeyi, taciz etmeyi ve zarar vermeyi amaçlayarak ( $\mathrm{Su}, \mathrm{McD}$ Donnell, Roth ve ark., 2021), kasıtlı bir biçimde güç kullanmayı içerir. Bireyin kendisine yönelik gösterdiği şiddete örnek olarak intihar ve kendisine zarar verme davranışları; kişilerarası şiddete örnek olarak partnere, çocuğa ve yaşliya yönelik gösterdiği zarar verme davranışları; toplumsal şiddete örnek olarak yabancılara yönelik gösterilen zarar verme davranışları gösterilebilir (Rutherford, Zwi, Grove ve Butchart, 2007). Şiddet, fiziksel, duygusal, cinsel (Okuda, Olfson, Hasin ve ark., 2011; Tun ve Ostergren, 2020) ve ekonomik şiddet biçiminde ortaya çıkabilir (Rada, 2014). Şiddete maruz kalan bireyin psikolojik durumu olumsuz olarak etkilenir. Fiziksel ve ruhsal sağlık sorunlarıyla kendini gösteren ciddi sağlık sorunları ortaya çıar ( $\mathrm{Su}, \mathrm{McD}$ onnell, Roth ve ark., 2021). Yaralanmalar, kırıklar olup (Mundodan, Lamiya ve Haver, 2021), ölüme de yol açar (Tun ve Ostergren, 2020). Bu nedenlerle, şiddet tehlikelidir.

Şiddetle ilgili yapılan araştırmalara bakıldığında, en çok şiddete uğrayan gruplardan birisinin de kadınlar olduğu görülmektedir (Walby ve Towers, 2017). Kadına yönelik şiddet, kadının psikolojik, fiziksel ya da cinsel açıdan zarar görmesiyle sonuçlanan; baskıyı, tehditi ve özgürlüğün engellemesini de içeren, cinsiyete dayalı her türlü şiddeti içerir (Ünal ve Gülseren, 2020). Bu şiddetler, sözlü tacizleri, tehditleri, korkutmaları, manipülatif davranışları, tecavüzü ve hatta cinayet olaylarını içeren davranışlardan oluşmaktadır (Golding, 2002). Dünya genelinde her üç kadından birisi, fiziksel ve/veya cinsel şiddetle karşılaşmaktadır (WHO, 2019). Şiddet olaylarının yaklaşık \%80'i yakın ilişki içerisinde bulunulan kişiden gelmektedir (Hogg ve Vaughan, 2011). Kadınlar, daha çok erkekler tarafından çeşitli şiddet türlerine maruz kalmaktadırlar (Machado, Martins ve Caridade, 2014; Özateş, 2009). Şiddeti uygulayan kişinin de genellikle kadının eşi olduğu görülmektedir (WHO, 2019). Nitekim, dünyada ve Türkiye' de gerçekleştirilen araştırmalarda, kadınların eşlerinden şiddet gördüğü ortaya konulmuştur (Arslan, Yarımoğlu, Çekin ve Hilal, 2005; Başar ve Demirci, 2015; Başkale ve Sözer, 2015; Chen, Yu, Luo ve Huang, 2016; Chuemchit ve ark., 2018; Kazaura, Ezekiel ve Chitama, 2016; Nybergh, Taft, Enander ve Krantz, 2013; Rurangirwa, Mogren, Ntaganira ve Krantz, 2017; Tun ve Ostergren,2020; Thomas ve ark., 2019; Vameghi ve ark., 2018). En sık görülen eş şiddeti içinde itmek, tokat atmak, tekme atmak, 1sırmak, bedene vurmak/dövmek, bir şeyle vurmak, boğmak, bıçakla tehdit etmek (Burczycka, 2014), silahla tehdit etmek (Tun ve Ostergren, 2020); yakmak, bir yere kilitlemek, parasını almak ya da para vermemek, küfür etmek (Rivera, 2004), hakaret etmek (Tun ve Ostergren, 2020); başkalarının yanında aşağılamak, küçük düşürmek, tehdit etmek, kolu bükmek, saç çekmek, cinsel birlikteliğe zorlamak ve zorla cinsel ilişkiye girmek vardır (Orindi, Ziraba, Bruyneel ve ark., 2021).

Kadına yönelik şiddete ilişkin ülkemizdeki Türkiye İstatistik Kurumu'nun resmi istatistik raporu incelendiğinde verilerin 2008 ve 2014 yılları ile sınırlı olduğu görülmektedir (TÜIK, 2020). Türkiye İstatistik Kurumu 2014 yılı verileri, Türkiye genelinde en az bir kez evlenen ve yaşamındaki herhangi bir dönemde eşinden ya da birlikte olduğu erkekten fiziksel ve/veya cinsel şiddet gören toplam kadın sayısının 6287 olduğunu, bu kadınların \%35'inin fiziksel, \%11.8'inin cinsel, \%36.9'unun ise fiziksel ve/veya cinsel şiddete maruz kaldıklarını ortaya 
koymaktadır (TÜİK, 2020). Bu veriler, kayda geçen verilerdir. Kayıtlara geçmeyen ve eşinden/partnerinden şiddet gören birçok kadın da bulunmaktadır. Şiddeti yaşayan kadınlar, şiddet durumunu gizlemeye çalışarak yaşanan şiddetin etkilerini azımsama eğiliminde olabilmektedirler (Gladding, 2012). Şiddet, özel bir alanda gerçekleştiğinden şiddeti gizleyebilmektedirler. Kadınların şiddet konusunda nasıl ve nereden yardım alacaklarını bilmeyerek çaresiz kalmaları (Akkaş ve Uyanık, 2016); ve şiddetten ötürü damgalanma "yaftalanma" kaygısı gibi psikolojik nedenler, şiddet düzeyini değerlendirmeyi ve şiddetin tespit edilmesini güçleştirmektedir (Gladding, 2012). James (1994), şiddeti resmi makamlara bildirme konusundandaki isteksizliğin yasal sonuçlarından endişe duyulmasından ve ilişkiyle ilgili suçluluk ve utancın duyulmasından kaynaklandığını belirtmektedir.

Şiddet gösteren erkekler aile ortamında yetiştirilirken, aile içi şiddete tanık olabilmekte; dayak, taciz gibi kötü muameleye maruz kalabilmektedirler. Bu sağlıksız yetişme ortamına, eğitim düzeyinin düşük olması (WHO, 2019), düşük ekonomik yaşam koşulları, geleneksel toplumsal cinsiyet tutumları, şiddet içeren davranışlara hoşgörüyle yaklaşan bir çevre (Rada, 2014), alkol ve uyuşturucu madde kullanımı, çocukluktan itibaren duyulan toplumsal erkeklik yargıları, güç ve kontrol kurma anlayışları (Turhan, 2019), ataerkil bir anlayış ile erkek otoritesini temel alarak kadına şiddet göstermenin (Özkazanç ve Yetiş, 2016), kadını hor görmenin olağan bir durum olduğu inanc1 .vb. gibi etmenler eklendiğinde, risk faktörleri daha da artmaktadır. Ataerkil anlayıştan güç alan erkek, eşine psikolojik ve/veya fiziksel şiddeti gösterir (Gödelek, 2005). Bulut'un (2017) belirttiği, "kadının sırtından sopayı, karnından stpayı eksik etmeyeceksin", "kocanın vurduğu yerde gül biter", "kızını dövmeyen dizini döver"şeklindeki atasözleri; ve "karı ă̆ızlı", "saçı uzun aklı kısa", "elinin hamuruyla erkek işine karışmak" deyimleri ile büyüyen erkek çocuklarının yetişkin olduklarında eşlerine şiddet göstermeleri beklenilen bir durumdur. Ayrıca, kadınların erkeklere göre daha düşük statüde olmaları, kadınların istihdam edilme oranlarının düşük olması (WHO, 2019) ve kadınların ekonomik bağımsızlıklarının olmaması, yani çalışmamaları da eşinden şiddet görmelerine neden olan risk faktörlerindendir (Eşkinat, 2013). Yapılmış olan bazı araştırmalarda kadınların çalışmamaları ile eşinden şiddet görmeleri arasında ilişki bulunmuşken (Çetiner, 2006; Kocacık ve Doğan, 2006; Okyay, Atasoylu, Önde, Dereboy ve Beşer, 2012; Uçar, 2011; Yanıkkerem, 2002); bazı araştırmalarda ise kadınların çalıştıkları halde eşlerinden şiddet gördükleri bulunmuştur (Sağkal, Kalkım, Sülü-Uğurlu ve Ersoy-Kırmızılar, 2014; Tel, Kocataş, Güler, Tel-Aydın ve Akgül-Gündoğdu, 2019). Yani kadınlar çalışsalar da, çalışmasalar da eşlerinden şiddet görebilmektedirler. Aslında kadınların çalışması, ekonomik bağımsızlıklarını kazanarak bireysel gelişimlerini sağlamaları için önemlidir (Kuzgun ve Sevim, 2004). Çalışma yaşamı, bireylerin zihinsel ve bedensel etkinliklerini gerçekleştirdikleri (Özaydın ve Özdemir, 2014); ekonomik, kültürel, psikolojik ve sosyal yönlerden doyum sağladıkları ortamlardır (Turan, 2018; Yüksel Şahin ve Taşkın 2019).

Çalışma yaşamı kadınların kendi kararlarını alıp, söylemeleri için cesaret verir. Kadınları özgürleştirir. Kendilerine olan güvenlerini (Alp, 2007), benlik saygılarını, sosyal iletişimlerini, karar verme becerilerini arttırır. Düzenli olarak aktif olmalarını sağlar (Harnois ve Gabriel, 2002). Fiziksel, sosyal ve duygusal sağlık açısından (Taylor, Peplau ve Sears, 2012); ve ekonomik açıdan güçlenmelerini sağlar. Zira çalışmak, geliri, aktivite yapmayı, sosyal ilişkilere girmeyi ve mesleki kimliği sağlayarak bireye ödül sağlar. Çalışmayan bireyler bu ödüllerden yoksun kalırlar (Sorensen ve Verbrugge, 1987). Bütün bu açılardan bakıldığında çalışmak ve üretken 
olmak kadınların mutlu olmasına, kendini gerçekleştirmesine katkı getirir (Yüksel Şahin ve Taşkın 2019). Psikososyal iyi oluşu ve ruh sağlığı üzerinde olumlu etkileri yapar (Harnois ve Gabriel, 2002). Bu nedenlerle kadınların çalışması, eş şiddetinden kendilerini korumalarında önemli bir koruyucu faktördür. Yapılmış olan araştırmalarda, ücretli istihdamla çalışmanın, kadınların ruh sağlığı üzerinde olumlu etkileri olduğunu göstermektedir. Ayrıca, birden fazla rolün ruh sağlığı üzerinde olumsuz etkilerden ziyade yararlı olduğunu da göstermektedir (Dennerstein,1995). Rosenfield (1989) yapmış olduğu araştırmanın sonucunda, işin ve ailenin taleplerini dengeleyebilen çalışan kadınlardaki kaygı ve depresyon belirtilerinin, çalışmayan ev kadınlarına göre önemli ölçüde daha düşük olduğunu bulmuştur. Sorensen ve Verbrugge (1987), çalışan evli kadınların çalışmayan ev kadınlara oranla, daha az psikiyatrik belirtileri gösterdiklerini ve sosyal rollerine daha iyi uyum sağladıklarını, görevlerini daha etkili bir biçimde yerine getirdiklerini belirtmektedirler. Kadınlar, çalışma yaşamında olup ekonomik olarak şiddet gösteren eşe bağımlı olmadıklarında da, eş şiddetinden kendilerini korumaları mümkün olabilir. Ayrıca Kuzgun ve Sevim' in (2004); Yüksel-Şahin ve Taşkın'ın (2019) belirttiği gibi, kadınların çalışma yaşamında olmaları bireysel gelişimlerini sağlamaları için önemlidir. Bireysel gelişim sürecinde de kişinin eylemliliği/çok yönlü eylemli kişiliği önemlidir (Atak, 2011). Eylemlilik ya da eylemli kişilik, bireyin yaşamı sürecinde ilerlemesini engelleyen engellerin üstesinden gelebileceğine olan inancını, kararlarını, kararlarının sonuçları üzerindeki kontrolünü ve sorumluluk duygusuna sahip olmasını içerir (Schwartz, Cóté ve Arnett, 2005).

Çok yönlü eylemli kişilik içinde yaşam amaçları, öz yeterlilik, öz saygı ve içsel denetim ögeleri vardır. Eylemli kişiliği yüksek düzeyde olan bir bireyin yaşam amaçları olup, daha aktiftir. Öz yeterliliği, öz saygısı, içsel denetimi daha yüksek düzeydedir (Côté, 1997). Bireyin kendisi için amaçlar koyması ve istenen sonuçları üretebilecek planlar yapması önemlidir (Bandura, 1989). Yaşam amaçları, uzun süreli amaçlar olup (Eryılmaz, 2012a); bireyin yaşamını anlamlandırmasına yardımcı olur (Eryılmaz, 2012b). Bireyin yaşamından ne istediğini ve ne tür bir yaşam sürmek istediğini de yansıtır (Lüdtke, Trautwein ve Husemann, 2009). Öz yeterlilik, bireyin kendi davranışını kontrol edebilmesi, nasıl davranacağıyla ilgili kararları kendisinin verebilmesi (Senemoğlu, 2012), sorunlarının çözümü için çaba harcaması, çabasında 1srarcı olması, bu değişimi gerçekleştirebileceğine dair inancıyla ilgilidir (Burger, 2006). Bireyin başa çıkma ve başarılı olma becerisine yönelik değerlendirmelerinin göstergesi de öz yeterliliktir (Judge ve Bono, 2001). Öz saygı, bireyin kendisine karşı olumlu ve olumsuz tutumlarını içeren ve aynı zamanda psikolojik iyi oluşuyla da ilişkili olan bir kavram (Rosenberg, Schooler, Schoenbach ve Rosenberg, 1995) olup; kendisine bir kişi olarak verdiği toplam değeri temsil eder (Judge ve Bono, 2001). İçsel denetim, bireyin olayları denetlemenin kendi elinde olduğuna inanmasıdır (Rotter, 1966). Çalışan kadınların bireyselleşme sürecinde çok yönlü eylemli kişilik özelliklerini içeren yaşam amaçlarına, öz yeterliliğe, öz saygıya ve içsel denetim odağına sahip olması beklenir. Ancak, çalışıyor olsa da eşinden şiddet gören kadınların eylemli kişilikte yer alan kendisi için amaçlar belirlemede ve planlar yapmada zorlanması, aktif olup harekete geçmede sorun yaşaması, kendisini yeterli görmemesi, öz saygısının ve içsel denetiminin düşük olması da olasıdır.

Eşinden şiddet gören kadınların ruh sağlıkları olumsuz olarak etkilenir. Ruh sağlığı, bireyin kendi yeteneklerinin farkına vardığı, yaşamın normal gerginlikleriyle başa çıkabildiği, üretken ve verimli bir şekilde çalışabildiği ve içinde yaşadığı topluma katkıda bulunabildiği bir iyilik 
hali (Taycan ve Coşkun, 2020) olarak tanımlamaktadır. Ruh sağlığı sürekliliği, psikopatolojinin olmadığı durumları tanımlamada kullanılır (Keyes ve Annas, 2009). Ruh sağlığı sürekliliği, psikolojik iyi olmayı, duygusal iyi olmayı ve sosyal iyi olmayı içerir. Psikolojik iyi olma durumu, bireyin benliğini olumlu algılamasını, yaşamındaki amaçlarının farkında olmasını, sağlıklı ilişkiler kurmasını, özgür ve girişimci olmasını, sınırlılıklarını kabul edip kendisiyle bütünleşmesini, kendi ihtiyaçlarını dikkate almasını, yeteneklerinin farkında olmasını ve kendini geliştirmesini içerir (Ryff, 1989). Duygusal iyi olma, mutlu olmayı, yaşama ilişkin olumlu duygular içinde olmayı içerir (Keyes ve ark., 2008). Sosyal iyi olma, bireyin sosyal gelişimini, sosyal uyumunu, sosyal katılımını içerir (Keyes, 1998). Eşinden şiddet gören kadınların karşılaştıkları şiddet türüne ve şiddetin sürekliliğine bağlı olarak ruh sağlı̆̆ sürekliliğinde yer alan psikolojik iyi olmada, duygusal iyi olmada ve sosyal iyi olmada sorunlar yaşaması mümkündür. Şiddete maruz kalmanın sıklığı arttıkça, psikiyatrik bozukluk geliştirme riskinin de arttığı belirtilmektedir. Yapılmış olan araştırmalarda, partner şiddetine maruz kalan bireylerde depresyon, travma sonrası stres bozukluğu, kaygı, kendine zarar verme davranışlarının ve uyku bozukluklarının ortaya çıtı̆̆ı bulunmuştur. Özellikle, fiziksel, cinsel ve psikolojik/duygusal şiddet türlerini birlikte yaşamanın, depresif belirtilere sahip olma olasılığını ve şiddetini artırdığı bulunmuştur (Dillon, Hussain, Loxton ve Rahman, 2013).

Eşinden şiddet gören kadınların geleneksel cinsiyet rolü içinde olduğunu söylemek mümkündür. Kadına yönelik şiddet, bir yandan fiziksel, cinsel ya da psikolojik acı veren cinsiyete dayalı eylemleri kapsar (Kadınlara Karşı Şiddetin Tasfiye Edilmesi, 1993). Cinsiyet eşitsizliği, kadına yönelik şiddete neden olmaktadır. Geleneksel ataerkil yapıda kadınlardan itaat etmelerini beklemek, güçlü kadınların damgalanması ya da saygı görmemesi cinsiyete dayalı şiddete katkıda bulunmaktadır (Tang, 2021). Toplumsal cinsiyet rolleri, geleneksel olarak kadın ve erkekle ilişkilendirilen rolleri içerir (Vefikuluçay-Yılmaz ve ark., 2009; Türk, 2008). Bem'in (1981) tanımladığı cinsiyet rolleri kadınsı, erkeksi, androjen ve belirsiz cinsiyet rolü biçimindedir. "Kadınsı cinsiyet rolü", düşük düzeyde erkeksi özellikleri ve yüksek düzeyde kadınsı özellikleri; “erkeksi cinsiyet rolü”, düşük düzeyde kadınsı özellikleri ve yüksek düzeyde erkeksi özellikleri; "androjen cinsiyet rolü”, yüksek düzeyde erkeksi özellikleri ve yüksek düzeyde kadınsı özellikleri, "belirsiz cinsiyet rolü", düşük düzeyde erkeksi özellikleri ve düşük düzeyde kadınsı özellikleri içerir. Toplumsal cinsiyet rollerine, geleneksel ve eşitlikçi açıdan bakıldığında, kadınların ev işlerinden sorumlu olması, çalışma hayatında pasif konumda olması geleneksel cinsiyet rolleri içerisindeyken; kadınların ve erkeklerin aile, iş, evlilik, eğitim ve sosyal yaşantılarında eşit haklara ve sorumluluklara sahip olmaları eşitlikçi cinsiyet rolleri içerisinde değerlendirilmektedir (Zeyneloğlu, 2008). Geleneksel toplumsal cinsiyet rollerinin dışına çıkılmış eşitlikçi bir aile ortamında büyümek bireyin olumlu benlik kavramına, yüksek benlik saygısına, sağlıklı ilişkileri kurmasına, kariyer hedeflerini özgürce belirleyebilmesine, sağlıklı psikolojik gelişimine ve iyi oluşuna katkı getirir (Saygan ve Peken-Uludağlı, 2021). Aile içinde bu şekilde yetişmiş olan ve eşitlikçi toplumsal cinsiyet rollerine sahip kadınlar, eşlerinden şiddet görebilme ihtimalinde bile kendilerini koruyarak eşlerinden uzaklaşabilirler. Eğer şiddet görürlerse, bu durumun insan hakları ihlali olduğunun farkına vararak şiddete karşı gelebilirler. Eşitlikçi toplumsal cinsiyet rollerine sahip kadınların da eşlerinden şiddet görme olasılıklarının daha az olduğu söylenebilir. Kadınların çalışma durumu, toplumsal cinsiyet rolleri bağlamında da eşlerinden şiddet görme durumlarını engelleyen, ruh sağlıklarını koruyan faktörlerden birisi olarak ele alınabilir. 
Bu araştırmada, eşinden şiddet görmenin ve görmemenin çalışan kadınların çok yönlü eylemli kişilik özelliklerini, ruh sağlığı sürekliliklerini ve toplumsal cinsiyet rollerini anlamlı bir biçimde yordayıp yordamadığı incelenmiştir. Alan yazına bakıldığında şiddet ya da kadına yönelik eş şiddeti ile çok yönlü eylemli kişilik özellikleri ve ruh sağlığı sürekliliği arasındaki ilişkileri inceleyen araştırmalara rastlanılamamıştır. Diğer yandan, şiddet ya da kadına yönelik eş şiddeti ile toplumsal cinsiyet rolleri arasındaki ilişkileri inceleyen araştırmaların olduğu bulunmuştur Yapılmış olan araştırmalarda, örneğin; şiddet eğilimi arttıkça geleneksel toplumsal cinsiyet rol puanlarının arttığı (Kodan Çetinkaya, 2013); geleneksel toplumsal cinsiyet rolleri tutumlarına sahip olan ergenlerin flört şiddetini haklı buldukları ve yüksek düzeyde flört şiddetine maruz kaldıkları (Lichter ve McCloskey, 2004); geleneksel cinsiyet rolleri tutumlarına sahip erkek ergenlerin daha fazla flört şiddetini gösterdikleri (McNaughton-Reyes, Foshee, Niolon, Reidy ve Hall, 2016); geleneksel cinsiyet rolleri tutumlarına sahip olan erkeklerin eş/partner ilişkilerinde şiddet gösterdikleri (Santana, Raj, Decker, La Marche, Silverman, 2006) bulunmuştur. Alanyazında araştırmamızın konusu olan eş şiddeti ile çok yönlü eylemli kişilik ve ruhsağlı̆̆ sürekliliğiyle ilgili araştırmaların olmaması; toplumsal cinsiyet rolleriyle ilgili fazla sayıda araştırmaların olmaması nedeniyle bu araştırmada eşinden şiddet gören ve görmeyen çalışan kadınların çok yönlü eylemli kişilik özellikleri, ruh sağlı̆̆1 süreklilikleri ve toplumsal cinsiyet rolleri incelenmiştir. Bu bağlamda araştırmanın alan yazına bir ölçüde de katkıda bulunacağ umulmaktadır. Ayrıca, yapılmış olan bu araştırma kadına yönelik şiddete dikkat çekmesi açısından da önemli olabilir. Psikolojik, duygusal, sosyal olarak iyi oluşa sahip olan; kendine güvenen, özsaygısı yüksek, içsel denetime sahip, yaşam amaçları olumlu olup, eşitlikçi toplumsal cinsiyet rolllerine sahip olan kadınların yetiştirecekleri çocuklar da psikolojik olarak daha güçlü olacaklardır. Sağlıklı nesillerin yetiştirilmesinde kadının şiddetten korunması ve güçlendirilmesi önemli olup, konuyla ilgili yeni araştırmaların yapılmasını ve önlemlerin alınmasını da teşvik edebilir.

\section{YÖNTEM}

$\mathrm{Bu}$ araştırma, çalışan kadınların eşinden gördükleri şiddetin çok yönlü eylemli kişilik, ruh sağlığı sürekliliği ve toplumsal cinsiyet rolleri düzeylerini anlamlı bir biçimde yordayıp yordamadığını incelemeyi amaçlayan nicel yöntemi içeren tarama desenli bir çalışmadır. Tarama deseni, örneklem üzerinde yapılan çalışmalar sonucunda, bireylerin eğilim, tutum ya da görüşlerin nicel olarak betimlenmesini sağlar (Creswell, 2017). Araştırmada, kullanılan ölçekleri geliştiren araştırmacılardan gerekli izinler alınmıştır. Ölçeklerin uygulanmasından önce katılımcılar, araştırmanın amacı ve veri toplama araçları ile ilgili olarak bilgilendirilmiştir. "Bilgilendirilmiş Onay Formu” ile katılımcıların onayları alınmıştır.

\section{Çalışma Grubu}

$\mathrm{Bu}$ araştırmada çalışma grubuna, kartopu örnekleme ve amaçlı örnekleme yöntemleri ile ulaşılmıştır. Araştırma grubunu 695 evli ve çalışan kadın oluşturmuştur. Evli ve çalışan kadınlara internet üzerinden Google Online Form aracilığıyla ulaşılarak ölçme araçları uygulanmıştır. Araştırmaya katılan çalışan kadınlar, devlet kurumlarında ve özel kurumlarda memur, işçi, esnaf, serbest meslek sahibi ve diğer meslekler olarak çalışmaktadırlar. 695 evli kadının \%26.6'sı (n=185) 19-25 yaş aralığında, \%45.2'si (n=314) 26-30 yaş aralığında, \%23.6'sı $(n=164)$ 31-35 yaş aralığında, \%3.7'si $(n=26)$ 36-40 yaş aralığında, \%0.6'sı $(n=4)$ 41-50 yaş aralığında ve \%0.3'ü $(\mathrm{n}=2) 51$ yaş ve üzerindedir. Kadınların mesleklerine bakıldığında 
\%38.1'nin ( $\mathrm{n}=265)$ memur, \%18.8'inin ( $\mathrm{n}=131)$ işçi, \%7.1'inin ( $\mathrm{n}=49)$ serbest meslek, \%1.9'unun $(n=13)$ esnaf, \%0.6'sının ( $n=4)$ emekli, \%33.5' inin $(n=233)$ diğer olduğu görülmektedir.

\section{Veri Toplama Araçları}

Araştırmada veri toplama araçları olarak Aile İçi Kadına Yönelik Şiddet Ölçeği, Çok Yönlü Eylemli Kişilik Ölçeği, Ruh Sağlığı Sürekliliği Kısa Formu ve Toplumsal Cinsiyet Rolleri Tutum Ölçeği kullanılmıştır. Ölçeklerin geçerlik ve güvenirlik çalışmaları olduğu için bu araştırma kapsamında yeniden geçerlik ve güvenirlik çalışmaları yapılmamıştır.

Aile İçi Kadına Yönelik Şiddet Ölçeği. Bu araştırmada çalışan ve evli kadınların, eşlerinden gördükleri fiziksel, duygusal, ekonomik ya da cinsel şiddeti belirlemek için Aile İçi Kadına Yönelik Şiddet Ölçeği kullanılmıştır. Kılıç (1999), tarafından geliştirilen bu ölçek, kadına eşi tarafından aile içinde uygulanan şiddetin düzeyini ve boyutlarını belirlemeye yardımcı olmaktadır. Ölçek, 50 maddelik ve 3'lü likert tipi bir ölçme aracıdır. Ölçeğin madde toplam güvenirlik katsayıları $\mathrm{r}$ değerlerinin, .25 ile .77 arasında değiştiği tespit edilmiştir. Ölçeğin iç tutarlığı ve homojenliğini incelemek amacıyla yapılan Kuder Richardson 20 Güvenirlik Analizi sonucunda, ölçek ve alt grupları için $\alpha$ değerlerinin şiddet ölçeği toplamı için .94 olarak tespit edilmiştir. Ölçeğin tamamı ile alt gruplarının $\alpha$ değeri ise .70' in üzerindedir.

Çok Yönlü Eylemli Kişilik Ölçeği. Çalışan ve evli kadınların çok yönlü eylemli kişilik özelliklerini belirlemek için Çok Yönlü Eylemli Kişilik Ölçeği kullanılmıştır. Ölçek, Côté (2005), tarafından geliştirilmiş; kültürümüze uyarlama çalışması Atak, Kapçı ve Çok (2013) tarafından yapılmıştır. Ölçek, iç denetim odağı, eylemliliğin öz yeterlilik, yaşam amaçları ve öz saygı boyutlarının incelenmesini sağlamaktadır. Ölçek, 5'li likert tipi, 15 maddeliktir. Ölçeğin güvenilirlik çalışması için, ölçeğin tümü için Cronbach $\alpha .=81$; test-tekrar test güvenilirlik katsayısı $.87^{\prime}$ dir. Ölçeğin madde analizi sonuçlarına göre, düzeltilmiş madde toplam korelasyonlarının .53. ile 31 arasında bulunmuştur. Açımlayıcı, doğrulayıcı ve ikinci düzey doğrulayıcı faktör analizi, 4 alt ölçekten oluşan ölçeğin varyansın \%57.43'ünü açıkladığını ve eylemliliği ölçmek için uygun olduğunu göstermiştir

Ruh Sağhı̆ğ Sürekliliği Kısa Formu. Keyes ve ark. (2008), tarafından geliştirilen ve Demirci ve Akın (2015), tarafından kültürümüze uyarlama çalışmasının yapıldığı ölçek, ruh sağlı̆̆1 sürekliliğinin psikolojik iyi olma, duygusal iyi olma ve sosyal iyi olmayı ölçmektedir. 6 'lı likert tipi ve 14 maddelik bir ölçektir. Ölçeğin Cronbach $\alpha$ katsayısı, ölçeğin tümü için .90'dır. Birinci ve 2. düzey doğrulayıcı faktör analizi ile yapı geçerliğine bakılmıştır. Birinci düzey doğrulayıcı faktör analizinin uyum indeksleri (SRMR $=.049$, $\mathrm{RMSEA}=.079, \mathrm{CFI}=.97, \mathrm{GFI}=.92, \mathrm{NNFI}=.96$, $\left.\mathrm{NFI}=.96, \mathrm{RFI}=.95, \mathrm{IFI}=.97, \mathrm{x}^{2} / \mathrm{sd}=3,26, \mathrm{x}^{2}=235.41, \mathrm{sd}=72\right)$ modelin iyi uyum verdiğini göstermiştir. İkinci düzey doğrulayıcı faktör analizi uyum indeksleri de (NFI= .90, NNFI= .90, $\mathrm{SRMR}=.04,9 \mathrm{RMSEA}=.079, \mathrm{IFI} \mathrm{GFI}=.92,=.93, \mathrm{RFI}=.87, \mathrm{CFI}=.92, \mathrm{x}^{2} / \mathrm{sd}=3.26, \mathrm{x}^{2}=235.41, \mathrm{sd}=72$ ) modelin iyi uyum verdiğini göstermiştir. Madde analiziyle, ölçekteki maddelerin düzeltilmiş madde toplam puan korelasyonlarının . .68 ile .51'dir.

Toplumsal Cinsiyet Rolleri Tutum Ölçeği. Zeyneloğlu ve Terzioğlu (2011) tarafından geliştirilen ölçek, toplumsal cinsiyet rollerine ilişkin tutumları ölçmektedir. 5'li likert tipi, 38 maddelik bir ölçektir. Ölçekten alınan yüksek puanlar eşitlikçi tutumu, düşük puanlar ise geleneksel tutumu göstermektedir. Ölçek, beş alt cinsiyet rolü boyutundan oluşmaktadır. Bu beş cinsiyet rolü boyutu şöyledir: geleneksel, eşitlikçi, erkek, kadın ve evlilikte cinsiyet 
rolleridir. Ölçeğin, Cronbach $\alpha$ değeri .92' dir. Alt boyutlarına ilişkin Cronbach $\alpha$ değeri .80-.72 arasında değişmektedir. Ölçeğin alt faktörlerinin birbirleriyle olan korelasyonları .35-.65'dir. Madde toplam test korelasyonlarına r=.25-.70'dir. Ayrıca, madde analizine göre, \%27'lik üst ve alt gruplar için $\mathrm{t}$ değerleri arasında anlamlı farklılık bulunmuştur. Temel bileşenler analizi sonucunda, maddelerin faktör yüklerinin .35-.79 olduğu görülmüştür.

\section{Verilerin Analizi}

Problemin çözümü için öncelikle ölçeklerden alınan puanların normal dağılıp dağılmadığını görmek için puanların çarpıklık ve basıklık değerlerine bakılmıştır. Otokorelasyonun olup olmadığını öğrenmek için, Durbin-Watson Testi uygulanmıştır. Araştırmada, çok yönlü eylemli kişilik, ruh sağlığı sürekliliği ve toplumsal cinsiyet rolleri bağımlı değişkenler olarak ele alınmıştır. Eş şiddeti ise bağımsız değişken olarak ele alınmıştır. Çalışan kadınların Aile İçi Kadına Yönelik Şiddet Ölçeği'nden elde ettikleri puanların ortalaması bulunarak; ortalamanın 1 standart sapma altında olan puanlar 0, ortalamanın 1 standart sapma üzerinde olan puanlar 1 şeklinde kodlanmıştır.

Araştırmada, eşten şiddet görmenin çalışan kadınların çok yönlü eylemli kişilik, ruh sağlı̆̆ sürekliliği ve toplumsal cinsiyet rollerini anlamlı bir biçimde yordayıp yordanmadığını belirleyebilmek için Doğrusal Regresyon Analizi yapılmıştır. Doğrusal regresyon analizi ile bağımsız değişkenin, bağımlı değişkenle olan ilişkisi regresyon eşitliği ile açıklanmıştır. Regresyon analizinde hesaplanan F değeri ile modelin anlamlı olup olmadığı; hesaplanan $\mathrm{R}^{2}$ ile bağımsız değişkenin bağımlı değişkeni yordayıp yordamadığı; ve iki ortalama arasındaki farkı gösteren $t$ değeri de yazılmıştır (Tabachnick ve Fidell, ss. 135). $t$-değeri için grupların puan ortalamaları da verilmiştir.

\section{BULGULAR}

Araştırmada, çalışan kadınların eşinden şiddet görme ya da görmemelerinin çok yönlü eylemli kişilik, ruh sağlığı sürekliliği ve toplumsal cinsiyet rolleri düzeylerini anlamlı bir biçimde yordayıp yordamadığını belirlemek için doğrusal regresyon analizi yapılmadan önce, Çok Yönlü Eylemli Kişilik Ölçeği, Ruh Sağlığ Sürekliliği Ölçeği ve Toplumsal Cinsiyet Rolleri Tutum Ölçeği'nden elde edilen puanların normal dağılım gösterip göstermediğini belirlemek için alınan puanların çarpıklık ve basıklık katsayılarına bakılmış ve sonuçları Tablo 1'de gösterilmiştir. Ayrıca, Çok Yönlü Eylemli Kişilik Ölçeği, Ruh Sağlığı Sürekliliği Ölçeği ve Toplumsal Cinsiyet Rolleri Tutum Ölçeği'nden elde edilen puanların varyans ve kovaryans matrislerinin homojenliğini incelemek için Box's M Testi yapılmış; sistematik hatalara neden olan otokorelasyonun olup olmadığını belirlemek için de, Durbin-Watson Testi de yapılmış ve sonuçları Tablo 1'de gösterilmiştir. 
Eşinden Şiddet Gören ve Görmeyen Çalışan Kadınların Çok Yönlü Eylemli Kişilik Özelliklerinin, Ruh Sağlığı Sürekliliklerinin ve Toplumsal Cinsiyet Rollerinin İncelenmesi

Tablo 1. Çok Yönlü Eylemli Kişilik Ölçeği, Ruh Sağllğ̆ Sürekliliği Ölçeği ve Toplumsal Cinsiyet Rolleri Tutum Ölçeği Çarpıklık ve Basıklık Değerleri, Box's M Testi ve Durbin-Watson Testi

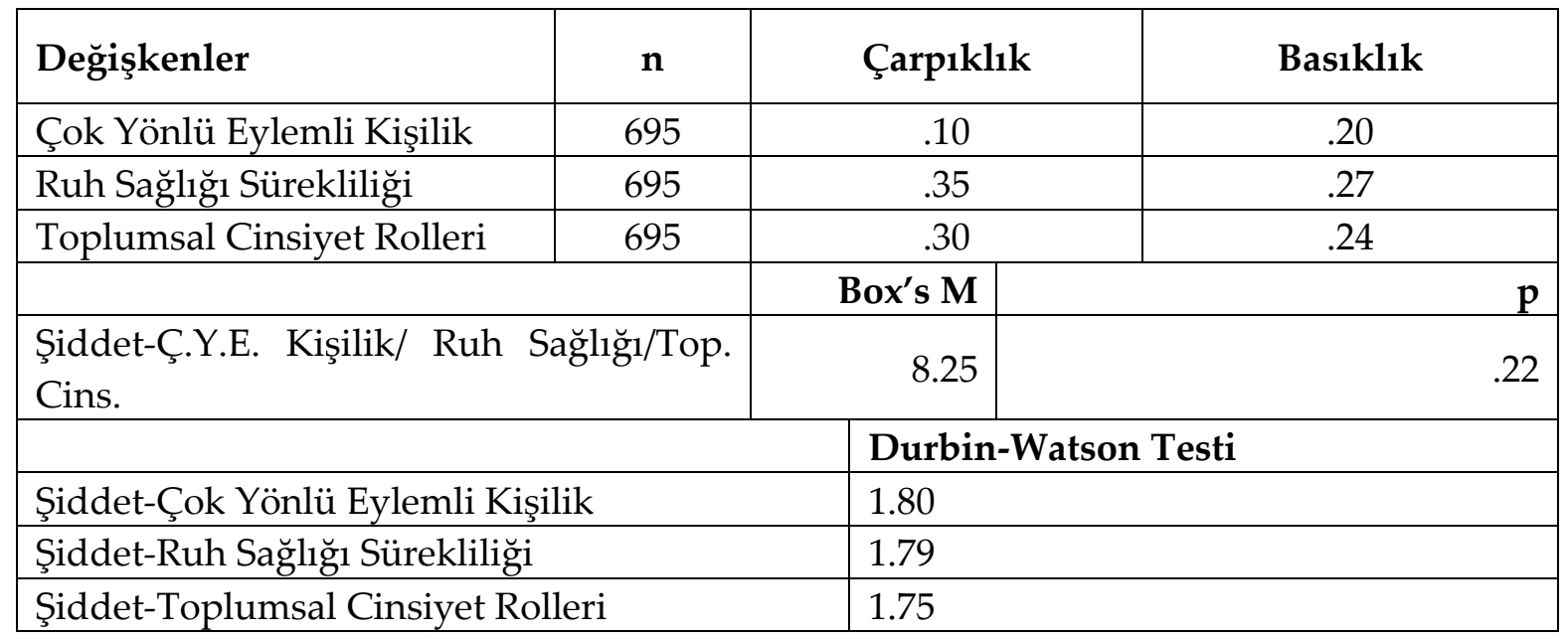

Tablo 1'de görüldüğ̈̈ gibi çarpıklık katsayılarına bakıldığında, Çok Yönlü Eylemli Kişilik Ölçeği için .10, Ruh Sağlığı Sürekliliği Ölçeği için .35 ve Toplumsal Cinsiyet Rolleri Tutum Ölçeği için .30 olmuştur. Basıklık katsayılarına bakıldığında Çok Yönlü Eylemli Kişilik Ölçeği için .20, Ruh Sağlığ 1 Sürekliliği Ölçeği için .27 ve Toplumsal Cinsiyet Rolleri Tutum Ölçeği için .24 olmuştur. Çarpıklık ve basıklık değerinin $+2,-2$ aralığında olması uygun görünür (Arapkirlioğlu ve Tankız, 2011).

Tablo 1'de görüldüğü gibi, Box's M Testi sonucunda eşinden şiddet görme, çok yönlü eylemli kişilik, ruh sağllğ ${ }_{1}$ sürekliliği ve toplumsal cinsiyet rolleri için Box's $M=8.25$ (p> .05) olarak bulunmuş olup varyans-kovaryans eşitliğinin sağlandığı görülmüştür. Eşinden şiddet görme ve çok yönlü eylemli kişilik için DW=1.80; eşinden şiddet görme ve ruh sağlığg sürekliliği için DW=1.79 ve eşinden şiddet görme ve toplumsal cinsiyet rolleri için DW=1.75 olarak bulunmuş ve Durbin-Watson Testi sonucunda da otokorelasyon olmadığı görülmüştür. 1.5-2.5 değeri, otokorelasyon olmadığını belirtir (Taşdan ve Erdem, 2010).

Araştırmada, çalışan kadınların eşinden şiddet görme ya da görmemelerinin çok yönlü eylemli kişilik, ruh sağlığı sürekliliği ve toplumsal cinsiyet rolleri düzeylerini anlamlı bir biçimde yordayıp yordamadığını belirlemek için doğrusal regresyon analizi yapılmıştır ve sonuçları Tablo 2' de gösterilmiştir. Ayrıca, Tablo 2' de eşinden şiddet görme ya da görmemeye göre çok yönlü eylemli kişilik, ruh sağlığı sürekliliği ve toplumsal cinsiyet rolleri puan ortalamaları da verilmiştir. 
Tablo 2. Eşinden Şiddet Görme ya da Görmemenin Çalışan Kadınların Çok Yönlü Eylemli Kişilik, Ruh Sağh̆ğ Sürekliliği ve Toplumsal Cinsiyet Rolleri Düzeylerini Yordamasma İlişkin Doğrusal Regresyon Analizi Sonuçları

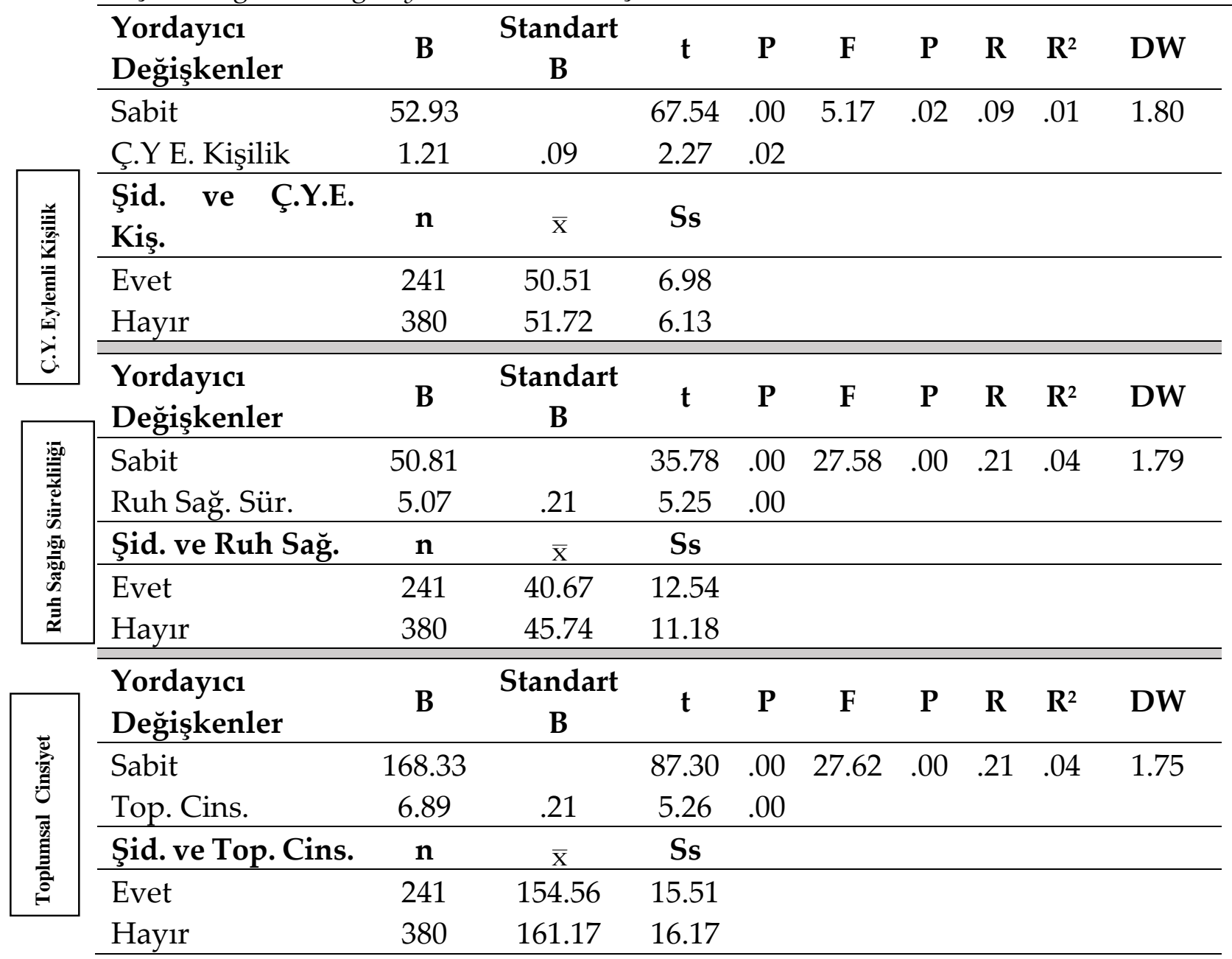

Tablo 2'ye bakıldığında, eşinden şiddet görme değişkeninin, çalışan kadınların çok yönlü eylemli kişiliklerinin (öz yeterlilik, öz saygı, iç denetim odağı ve yaşam amaçları) anlamlı bir yordayıcısı olduğu görülmektedir $\left(\mathrm{R}=.09, \mathrm{R}^{2}=.01 ; \mathrm{F}=5.17, \mathrm{p}<.02 ; \mathrm{t}=2.27, \mathrm{p}<.02\right)$. Çok yönlü eylemli kişiliğe ilişkin toplam varyansın \%.01'sinin, eşten şiddet görme durumu ile açıklandığ 1 ifade edilebilir. Ayrıca Tablo 2'ye bakıldığında, eşinden şiddet gören çalışan kadınların ( $\mathrm{n}=241)$ çok yönlü eylemli kişilik puan ortalaması ( $\bar{x}=50.51$, Ss=6.98), eşinden şiddet görmeyen çalışan kadınların ( $\mathrm{n}=380$ ) çok yönlü eylemli kişilik puan ortalamasından $(\overline{\mathrm{x}}=51.72, \mathrm{Ss}=6.13)$, anlamlı düzeyde $(\mathrm{t}=2.27, \mathrm{p}<.02)$ düşük bulunmuştur.

Tablo 2'ye bakıldığında, eşinden şiddet görme değişkeninin, çalışan kadınların ruh sağlığ1 sürekliliklerinin (duygusal iyi olma, sosyal iyi olma ve psikolojik iyi olma) anlamlı bir yordayıcısı olduğu görülmektedir $\left(\mathrm{R}=.21, \mathrm{R}^{2}=.04 ; \mathrm{F}=27.58, \mathrm{p}<.00 ; \mathrm{t}=5.25, \mathrm{p}<.00\right)$. Ruh sağlı̆̆ sürekliliğine ilişkin toplam varyansın \%.04'ünün, eşten şiddet görme durumu ile açıklandığı ifade edilebilir. Ayrıca Tablo 2'ye bakıldığında, eşinden şiddet gören çalışan kadınların $(n=241)$ ruh sağlığı sürekliliği puan ortalaması ( $\bar{x}=40.67, S s=12.54)$, eşinden şiddet görmeyen 
çalışan kadınların ( $\mathrm{n}=380)$ ruh sağlığı sürekliliği puan ortalamasından ( $\overline{\mathrm{x}}=45.74, \mathrm{Ss}=11.18)$, anlamlı düzeyde $(\mathrm{t}=5.25, \mathrm{p}<.00)$ düşük bulunmuştur.

Tablo 2'ye bakıldığında, eşinden şiddet görme değişkeninin, çalışan kadınların toplumsal cinsiyet rolleri tutumlarının anlamlı bir yordayıcısı olduğu görülmektedir $\left(\mathrm{R}=21, \mathrm{R}^{2}=.04\right.$; $\mathrm{F}=27.62, \mathrm{p}<.00 ; \mathrm{t}=5.26, \mathrm{p}<.00)$. Toplumsal cinsiyet rollerine ilişkin toplam varyansın \%.01'sinin, eşten şiddet görme durumu ile açıklandığı ifade edilebilir. Ayrıca Tablo 2'ye bakıldığında, eşinden şiddet gören çalışan kadınların $(n=241)$ toplumsal cinsiyet rolleri puan ortalaması ( $\bar{x}=154.56, S s=15.51)$, eşinden şiddet görmeyen çalışan kadınların $(n=380)$ toplumsal cinsiyet rolleri puan ortalamasindan $(\bar{x}=161.17, S s=16.17)$, anlamlı düzeyde $(t=5.26$, $\mathrm{p}<.00)$ düşük bulunmuştur. Bu bulgular, eşinden şiddet gören çalışan kadınların, toplumsal cinsiyet rollerine ilişkin geleneksel tutuma sahip olduğunu gösterirken; eşinden şiddet görmeyen çalışan kadınların, toplumsal cinsiyet rollerine ilişkin eşitlikçi tutuma sahip olduğunu göstermektedir.

\section{TARTIŞMA VE SONUÇ}

Araştırmanın sonucunda, eşinden şiddet görmenin çalışan kadınların çok yönlü eylemli kişiliklerinin, ruh sağlığı sürekliliklerinin ve toplumsal cinsiyet rollerinin anlamlı bir yordayıcısı olduğu bulunmuştur. Eşinden şiddet gören çalışan kadınların çok yönlü eylemli kişilik düzeylerinin, eşinden şiddet görmeyen kadınlarınkinden anlamlı düzeyde daha düşük olduğu bulunmuştur. Bu bulgu, eşinden şiddet gören çalışan kadınların çok yönlü eylemli kişiliği içeren öz yeterlilik, öz saygı, iç denetim odağı ve yaşam amaçlarının daha olumsuz olduğunu göstermektedir. Eşinden şiddet gören çalışan kadınların öz yeterlilik düzeyi düşük olduğunda, maruz kaldıkları şiddetle başa çıkabilme konusunda ihtiyaç duydukları eylem planlarını yürütmede zorluk çekerler. Ayrıca, maruz kaldıkları şiddet karşısında kendilerini ve yaşamlarını kontrol edebileceklerine dair inançları da zayıf olabilir. Öz saygı açısından eşinden şiddet gören çalışan kadınların kendilerine ilişkin değerlendirmeleri de daha olumsuz olabilir. Çalışan ve eşinden şiddet gören kadınlar, iç denetim odağı boyutunda maruz kaldıkları şiddeti, kontrol etme güçlerinin olduğuna inanmakta güçlük çekebilirler. Yaşadıkları şiddetin şanslarından, kaderlerinden kaynaklandığını düşünebilirler. Yaşam amaçları boyutunda ise çalışan ve eşinden şiddet gören kadınların nasıl bir yaşam sürmek istediklerini ve ne istediklerini tam olarak bilmediklerinden şiddet görme durumları ile ilgili de karar vermede ve seçim yapmada güçlük yaşadıkları söylenebilir. Gödelek (2005), eşlerinden şiddet gören kadınların ortak özelliklerinin içinde, yetiştikleri aile ortamında babalarından fiziksel şiddeti gördükleri ve pasif kalmaya zorlandıkları, boyun eğici oldukları ve kendilerine olan güvenlerinde düşüklük olduğunu belirtmektedir. Alan yazın incelendiğinde doğrudan kadına yönelik eş şiddeti ile çok yönlü eylemli kişilik arasındaki ilişkileri inceleyen araştırmalara rastlanılamamıştır. Ancak yapılmış olan araştırmalarda, ilişkilerinde şiddete maruz kalan kadınların ilişkiyi bitirme konusundaki öz yeterlilik inançlarıyla, ilişkiyi sonlandırdıkları (Lerner ve Kennedy, 2000); eş/partner şiddetine maruz kalmış kadınların maruz kaldıkları fiziksel şiddetin sayısı arttıkça, şiddetin uygulanma şekli kötüleştikçe, depresif belirtilerinin arttığı ve öz saygılarının azaldığı (Cascardi ve O'Leary, 1992); yüksek düzeyde içsel denetim odağına sahip olan ve eşinden şiddet gören kadınların ilişkilerini bitirme ve eşlerinden ayrılma olasılıklarının daha yüksek olduğu (Kim ve Gray, 2008) bulunmuştur. Çok yönlü eylemli kişiliği içeren öz yeterlilik, öz saygı, iç denetim odağı ile 
kadına yönelik eş şiddeti/şiddet konusunda yapılan bu araştırma bulguları, yaptığımız araştırmanın bulgusu ile örtüşmektedir.

Araştırmanın sonucunda, eşinden şiddet görmenin çalışan kadınların ruh sağlı̆̆ sürekliliklerinin anlamlı bir yordayıcısı olduğu bulunmuştur. Eşinden şiddet gören çalışan kadınların ruh sağlığı sürekliliği düzeyleri, eşinden şiddet görmeyen kadınlarınkinden anlamlı düzeyde daha düşük olarak bulunmuştur. Şiddet gören kadınların psikolojik iyi olma, duygusal iyi olma ve sosyal iyi olma düzeyleri düşük çıkmıştır. Araştırmanın bu bulgusuyla örtüşen alan yazın bilgilerinde, yaşanılan şiddet olaylarının, şiddete maruz kalan kadınlar için yıkıcı sonuçlara yol açtığı belirtilmektedir (Okan-İbiloğlu, 2012). Şiddete maruz kalan kadın, genelde yaşadıklarını ifade etmekte güçlük çeker (İncecik ve ark., 2009). Ayrıca depresyon, travma sonrası stres bozukluğu gibi ruh sağlığı sorunlarını da yaşar (Okan-İbiloğlu, 2012). Bu durum kadının ruh sağlığı sürekliliğini içeren duygusal iyi olma, sosyal iyi olma, psikolojik iyi olmasını da olumsuz yönde etkiler. Alan yazın incelendiğinde kadına yönelik eş şiddeti ile ruh sağlığ 1 sürekliliğgi arasındaki ilişkiyi inceleyen araştırmalara rastlanılamamıştır. Ancak, kadına yönelik eş şiddeti ile ruh sağlığı sürekliliğinin alt boyutları olan psikolojik iyi olma, duygusal iyi olma ve sosyal iyi olma arasındaki ilişkiyi inceleyen araştırmalar bulunmaktadır. Yapılmış olan araştırmalarda, şiddete maruz kalan kadınların psikolojik iyi oluş düzeylerinin düşük olduğu; ve psikolojik sağlamlığın kadınların psikolojik iyi oluşlarını yordamada önemli bir değişken olduğu (Altıntaş, 2019); eşinden şiddet gören kadınların psikolojik iyi olma ve sosyal iyi olma düzeylerinin, eşinden şiddet görmeyen kadınlarınkinden daha düşük düzeyde olduğu (Hassan ve Malik, 2012); şiddete maruz kalan kadınlarla iletişimi olan bireylerin de korku, panik, öfke, hayal kırıklığı, kaygı, sıkıntı, üzüntü ve suçluluk gibi duyguları yaşadıkları; duygusal iyi olma ve psikolojik iyi olma boyutlarında bir takım güçlükler yaşadıkları (Gregory ve ark. , 2017) bulunmuştur. Okuda, Olfson, Hasin ve ark.'ın (2011) yapmış oldukları araştırmanın sonucunda, yakın partner şiddetine maruz kalan kadınlarda, depresyon, travma sonrası stress bozukluğu, panik bozukluk, yaygın kaygı bozuklukları, alkol ve madde kulanımında artış, bipolar bozukluğun ortaya çıktığını bulmuşlardır (Okuda, Olfson, Hasin ve ark., 2011). Cascardi ve O'Leary (1992) yapmış oldukları araştırmanın sonucunda, yakın partner şiddetine maruz kalan kadınlarda, maruz kalınan fiziksel şiddetin sayısı arttıkça ve/veya şiddetin uygulanma şekli kötüleştikçe, kadınların depresif belirtilerinin arttığı ve öz saygılarının azaldığı bulunmuştur. Golding (1999), şiddete maruz kalan kadınlarda görülen ruhsal sorunların travma sonrası stres bozukluğu, depresyon, intihar eğilimi, alkol ve uyuşturucu kullanımı şeklinde olduğunu belirtmektedir. Alan yazındaki bu araştırma bulguları, araştırmamızın bulgusuyla örtüşmektedir.

Araştırmanın sonucunda, eşinden şiddet görmenin, çalışan kadınların toplumsal cinsiyet rollerinin anlamlı bir yordayıcısı olduğu bulunmuştur. Eşinden şiddet gören çalışan kadınların, geleneksel tutuma sahip olduğu, eşinden şiddet görmeyen çalışan kadınların ise eşitlikçi tutuma sahip olduğu bulunmuştur. Araştırmaya katılan çalışan kadınların \% 47.5'unun geleneksel cinsiyet rollerine sahip olduğu, \% 52.5'unun da eşitlikçi cinsiyet rollerine sahip olduğu bulunmuştur. Bu bulgudan, kadınlar çalışıyor olsalar da, geleneksel cinsiyet rollerine sahip olabildikleri de görülmektedir. Geleneksel toplumsal cinsiyet rolleri bağlamında kadınlar, aile ilişkileri içerisinde annedir, çocuklara birincil bakım veren kişidir, ev ve beslenme ile işleri ile ilgilenen kişidir. Erkekler ise baba olarak çocuklara ikincil bakım veren kişidir. Para kazanan 
kişi olarak nitelendirilir (Seçer, Çeliköz ve Yaşa, 2007). Geleneksel bakış açısı, kadınlar ve erkekler arasında eşitsizliğe neden olacak şekilde kadınların daha düşük statüde görülmesine neden olmaktadır (Aydın ve ark., 2016). Geleneksel toplumsal cinsiyet rollerinin etkisi ile kadınlar, şiddete uğramaktadır (Dinç-Kahraman, 2010). Kadınların ve erkeklerin aile, iş, evlilik, eğitim ve sosyal yaşantılarında eşit haklara ve sorumluluklara sahip olmaları eşitlikçi toplumsal cinsiyet rolleri içerisinde değerlendirilmektedir (Zeyneloğlu, 2008). Eşitlikçi toplumsal cinsiyet rol düzeyi yüksek olan bir birey ise karşısındaki bireyi "kadın" ya da "erkek" cinsiyet kategorilerine ayırıp onlara toplumun atfettiği cinsiyet rollerini yükleyerek toplumsal cinsiyet kalıp yargıları ile hareket etmez. Karşısındaki kişinin, birey olduğunun farkına vararak her bireyin değerli ve eşit olduğu inancıyla saygı ve empati temelli etkili bir iletişim kurar. Sağ lıklı ve etkili iletişim kuran bir birey, eş seçiminde kendisine uygun kararları daha kolay vererek eşitlikçi toplumsal cinsiyet rollerine sahip bir bireyle evlenebilir. Eşitlikçi toplumsal cinsiyet rollerine sahip bir eşle evli olan kadının ise eşinden şiddet görme olasılığ1 azalabilir. Bunun dışında eşitlikçi toplumsal cinsiyet rollerine sahip kadınlar, eşlerinden şiddet görseler dahi bu durumun insan hakları ihlali olduğunun farkına vararak karşılaştıkları şiddet durumlarıyla daha etkili bir şekilde başa çıkabilirler. Alan yazına bakıldığında yapılmış olan araştırmalar şiddet mağduru ya da faili olma ile geleneksel tutuma sahip olma arasında anlamlı bir ilişki olduğunu ortaya koymuştur (Kodan-Çetinkaya, 2013; Lichter ve McCloskey, 2004; McNaughton-Reyes ve ark., 2016; O’Brien ve ark., 2017; Santana ve ark., 2006). Akyüz'ün (2011) şiddet mağduru kadınlar üzerinde yapmış olduğu araştırmanın sonucunda, kadınların şiddete maruz kalma nedenleri olarak, \%45 oranında "söylenenlere karşılık vermek"; \%27 oranında "partnerin asabi yapısı" olarak belirttiklerini bulmuştur. Kadınların verdikleri bu yanitlar, sosyalizasyon sürecinde toplumsal cinsiyet rollerinin öğrenilmesi ile ilişkilendirilmiştir. Geleneksel toplumsal cinsiyet rollerine göre "bir erkek sinirli yapıda olabilir. Bu durum doğal karşılanmalıdır. Kadın da bu yüzden erkeğe karşı gelmeyerek susmalıdır", düşüncesi vardır. Yapılmış olan araştırmalarda, kadınların eğitim düzeyi arttıkça daha yüksek düzeyde eşitlikçi toplumsal cinsiyet rollerine sahip oldukları ve eşlerinden şiddet görme düzeylerinin daha düşük olduğu (Jewkes, Corboz ve Gibbs, 2018); kadın ve erkeklerin eğitim düzeyi arttıkça eşitlikçi toplumsal cinsiyet rollerinin arttı̆̆1 ve eş şiddetine yönelik davranışların azaldığ1 (Gibbs ve ark., 2018); geleneksel tutuma sahip katılımcıların, kadına yönelik fiziksel şiddeti meşrulaştırma düzeylerinin, eşitlikçi tutuma sahip katılımcılara göre daha yüksek olduğu (Küçükeskici, 2019) bulunmuştur. Alan yazındaki bu araştırma sonuçları, araştırmamızın bulgularıyla örtüşmektedir.

Sonuç olarak araştırma bulguları, eşten görülen şiddet ile çok yönlü eylemli kişilik, ruh sağlı̆̆ sürekliliği ve toplumsal cinsiyet rolleri arasında önemli ilişkilerin olduğunu ortaya koymaktadır. Eşinden şiddet gören çalışan kadınların öz yeterlilik, öz saygı, iç denetim odağ ve yaşam amaçlarının daha olumsuz olduğu görülmüştür. Şiddet gören kadınların psikolojik iyi olma, duygusal iyi olma, sosyal iyi olma düzeylerinin düşük olduğu; ve geleneksel toplumsal cinsiyet rollerine sahip oldukları da bulunmuştur. Araştırma sonuçlarından hareketle aşağıdaki öneriler sunulmuştur. 


\section{ÖNERİLER}

\section{Alan Araştırmacılarnna Yönelik Öneriler:}

-Bu araştırma, çalışan ve evli kadınlarla yürütülmüştür. Araştırmanın, çalışmayan ya da medeni durumu farklı kadınlarla da gerçekleştirilmesi yararlı olabilir.

-Bu araştırma, nicel araştırma teknikleri ile hazırlanmıştır. Araştırmanın, nitel veya karma araştırma teknikleri ile desteklenerek gerçekleştirilmesi daha kapsamlı bulgular elde edilmesinde yardımc olabilir.

\section{Psikolojik Danışmanlara, Eğitimcilere, Yasa Koyuculara ve Medyaya Yönelik Öneriler:}

-Araştırmanın sonucunda, eşinden şiddet gören çalışan kadınların çok yönlü eylemli kişilik düzeylerinin, eşinden şiddet görmeyen kadınlarınkinden anlamlı düzeyde daha düşük olduğu bulunmuştur. Araştırmanın bu sonucundan hareketle, kadınların şiddet görmesini engelleyebilmek için çok yönlü eylemli kişilik düzeylerini yükseltebilecek, öz saygı ve öz yeterlilik geliştirme programları ile kadınların çok yönlü eylemli kişilik özelliklerine sahip olması sağlanabilir. Böylece kadına yönelik şiddette çok yönlü eylemli kişilik, koruyucu bir faktör olarak kullanılabilir. Buna yönelik olarak psikolojik danışmanların psikoeğitim programlarını uygulamaları yararlı olacaktır.

- Araştırmanın sonucunda, eşinden şiddet gören çalışan kadınların ruh sağlı̆̆ı sürekliliği düzeyleri, eşinden şiddet görmeyen kadınlarınkinden anlamlı düzeyde daha düşük olarak bulunmuştur. Araştırmanın bu sonucundan hareketle, şiddet gören kadınlara yönelik yapılacak müdahale çalışmaları önem arz etmektedir. Şiddet gören kadınların ruh sağlı̆̆ı sürekliliklerini koruyacak önlemlerin alınarak kadınlara psikolojik danışma hizmetlerinin sunulması oldukça önemlidir.

- Araştırmanın sonucunda, eşinden şiddet gören çalışan kadınların, geleneksel tutuma sahip olduğu, eşinden şiddet görmeyen çalışan kadınların ise eşitlikçi tutuma sahip olduğu bulunmuştur. Araştırmanın bu sonucundan hareketle, kadınlara eşitlikçi toplumsal cinsiyet rollerine ilişkin bilgi verilerek toplumda kendilerini ifade etmelerine olanak sağlamak önemlidir. Ayrıca, cinsiyet eşitsizliğinden mağdur olmalarını engellemek için yalnızca kadınlara değil erkeklere de toplumsal cinsiyet eşitliği kapsamında bilimsel bilgiler sunmak, kadınların şiddete maruz kalmasını engelleme konusunda yardımcı olabilir. Toplumsal cinsiyet rollerine ilişkin bilgilerin her eğitim kademesindeki öğrencilere bilimsel bilgi ışığında sunulması öğrencilerin doğru bilgileri içselleştirmesinde ve eşitlikçi toplumsal cinsiyet rollerini davranışa dönüştürmesinde etkili olabilir. Bu konuda psikolojik danışmanlara, eğitimcilere ve medyaya da büyük görevler düşmektedir.

- Araştırmanın sonucunda, eşinden şiddet gören çalışan kadınların öz yeterlilik, öz saygı, iç denetim odağı ve yaşam amaçlarının daha olumsuz olduğu görülmüştür. Şiddet gören kadınların psikolojik iyi olma, duygusal iyi olma, sosyal iyi olma düzeylerinin düşük olduğu; ve geleneksel toplumsal cinsiyet rollerine sahip oldukları da bulunmuştur. Araştırmanın bu sonuçlarından hareketle, şiddetin, yalnızca şiddet mağdurlarını değil aynı zamanda şiddete tanık olan çocukları da etkilediğini söylemek mümkündür. Şiddete tanık olan çocukların duygusal ve davranışsal sorunları yaşamaları (Günşen İçli, 1994; Visser ve ark., 2015); ve gelecekte de şiddet davranışlarını göstermeleri olasıdır (Yaşar, 2017). Kadının eğitim almasının 
ve çalışmasının desteklenmesi kadar, yasalarla korunmasını da sağlamak gerekir. Kadının şiddetten korunması için “İstanbul Sözleşmesi” gibi "resmi yaptırımların yürürlükte olması" çok önemlidir. 20 Avrupa Konseyi Üyesi ülke tarafından onaylanan ve 1 Ağustos 2014 tarihinde yürürlüğe giren tam adı:"Kadına Yönelik Şiddet ve Aile İçi Şiddetin Önlenmesi ve Bunlarla Mücadeleye Dair Avrupa Konseyi Sözleşmesi"nde taraf devletler, sözleşmenin 4. maddesi ile kadına karşı ayırımcılık taşıyan tüm uygulamaları kaldırmayı taahhüt etmişlerdir. İstanbul Sözleşmesi, “yalnızca eşler arasında değil, yaşamın bütün alanlarında "kadınlara yönelik tüm tehdit ve şiddet içeren davranışlar" bakımından geçerlidir. Kadın kavramı, 18 yaşından küçükleri de kapsamaktadır. Kamusal ve özel alanlarda kadına karşı şiddeti engellemek, önlemek, şiddete karşı caydırıcı ceza hükümlerine sahip olmak konusunda, imzacı ülkelere pozitif yükümlülükler vermektedir (Şen ve Şahin, 2021).

-Şiddet gören kadınların şiddete maruz kaldıklarında, şiddetten korunmalarının sağlanmaları önemlidir. Bu amaçla, İçişleri Bakanlığının "Kadın Acil Destek Uygulamasını (KADES)" kullanarak yardım alabilecekleri konusunda medyadan "kamu spotlarının" yayınlamasının da yararı olacağı düşünülmektedir.

\section{KAYNAKÇA}

Akkaş, İ. \& Uyanık, Z. (2016). Kadına yönelik şiddet. Nevşehir Hacı Bektaş Veli Üniversitesi SBE Dergisi, 6(1), 32-42.

Akyüz, M. (2011). Aile içi şiddet mă̆duru kadınların sosyo-kültürel özelliklerinin incelenmesi: Diyarbakır ili örneği. Yüksek lisans tezi, Kara Harp Okulu, İstanbul.

Altıntaş, D. (2019). Şiddete maruz kalmaya bağgl olarak psikolojik dayanıklılık, bağışlayıcılık ve psikolojik iyi oluş arasındaki ilişkilerin incelenmesi. Yüksek lisans tezi, Ufuk Üniversitesi, Ankara.

Alp, A. (2007). Yeni çalışma biçimleri ve değişen aile yapısı bağlamında çalışan kadınlar. Tezsiz yüksek lisans projesi, Dokuz Eylül Üniversitesi, İzmir.

Arapkirlioğlu, H. \& Tankız, D. (2011). Müzik öğretmenliği programı özel yetenek sınavlarında alan ve yerleştirme puanlarının karşılaştırılması (İnönü Üniversitesi örneği). E-Uluslararası Eğitin Araştırmaları Dergisi, 2(4), 55-69.

Arslan M.M., Yarımoğlu, B., Çekin, N. \& Hilal, A. (2005). Eş şiddeti öyküsüyle adli tıp kurumu adana şube müdürlüğ̈̈'ne başvuran olguların incelenmesi. Türkiye Klinikleri, 2(2), 39-43.

Atak, H. (2011). Yetişkinliğe geçiş yıllarında sigara içme davranışının psikososyal belirleyicileri ve sigara içmenin yaşam doyumu ve öznel iyi oluşla ilişkisi. Klinik Psikiyatri Dergisi, 14(1), 29-43. 
Atak, H., Kapçı, E. G. \& Çok, F. 2013. Çok yönlü eylemli kişilik ölçeği'nin Türkçe formunun değerlendirilmesi. Düşünen Adam, 26, 36-45.

Aydın, M., Özen-Bekar, E., Yılmaz-Gören, Ş. \& Sungur, M. A. (2016). Hemşirelik öğrencilerinin toplumsal cinsiyet rollerine ilişkin tutumları. AİBÜ Sosyal Bilimler Enstitüsü Dergisi, 16(1), 223-242.

Bandura, A. (1989). Human agency in social cognitive theory. American Psychologist, 44(9), 1175-1184.

Başar, F. \& Demirci, N. (2015). Toplumsal cinsiyet eşitsizliği ve şiddet. Kadın Sağhı̆̆ı Hemşireliği Dergisi, 2(1), 41-52.

Başkale, H. \& Sözer, A. (2015). Eşinden/partnerinden şiddet gören kadınların şiddet algısı ve mağduriyet nedenleri. TAF Preventive Medicine Bulletin, 14(6), 468-474.

Bem, S. L. (1981). Gender schema theory: Cognitive account of sex typing. Psychological Review, 88(4), 354-364.

Bulut, S. (2017). Giresun ili ve yöresi ağızlarında kadın. Karadeniz Sosyal Bilimler Dergisi, 9(2), 325-355.

Burczycka, M. (2014). Trends in self-reported spousal violence in Canada. https://www150.statcan.gc.ca/n1/pub/85-002-x/2016001/article/14303/01-eng.htm

Burger, J. (2006). Kişilik. (İ. D. Erguvan Sarıŏlu, Çev.). Kaknüs Psikoloji.

Cascardi, M. \& O'Leary, K. D. (1992). Depressive symptomatology, self-esteem, and self-blame in battered women. Journal of family Violence, 7(4), 249-259.

Chen, L., Zonghuo Y., Xianming, L. \& Zhaoxin, H. (2016). Intimate partner violence against married rural-to-urban migrant workers in eastern china: prevalence, patterns, and associated factors. BMC Public Health, 16, 1232-1247.

Chuemchit, M., Suttharuethai, C., Rewat, R., Laddawan, D., Pajaree, A. \& Saskia E. W. (2018). Prevalence of intimate partner violence in Thailand. Journal of Family Violence, 33, 315-323.

Côté, J. E. (1997). An empirical test of the identity capital model. Journal of Adolescence, 20(5), 577-597.

Côté, J. E. (2005). Identity capital, social capital and the wider benefits of learning: generating resources facilitative of social cohesion. London Review of Education, 3(3), 221-237.

Creswell, J. W. (2017). Araştırma deseni. (S.B. Demir, Çev. Ed.). Eğiten Kitap.

Çetiner, Ş. G. (2006). Aile içi şiddet yaşayan kadınlarda cinsel sorunlar ve intihar olasıllı̆̆. Yüksek lisans tezi, Ankara Üniversitesi, Ankara.

Demirci, İ. \& Akın, A. (2015). Ruh sağlığı sürekliliği kısa formunun geçerliği ve güvenirliği. Ankara Üniversitesi Eğitim Bilimleri Fakültesi Dergisi, 48(1), 49-64.

Dennerstein, L. (1995). Mental health, work, and gender. International Journal of Health Services, 25(3), 503-509. 
Dillon, G., Hussain, R., Loxton, D. \& Rahman, S. (2013). Mental and physical health and intimate partner violence against women: A review of the literature. International Journal of Family Medicine, 1-15. https://doi.org/10.1155/2013/313909

Dinç-Kahraman, S. (2010). Kadınların toplumsal cinsiyet eşitsizliğine yönelik görüşlerinin belirlenmesi. Dokuz Eylül Üniversitesi Hemşirelik Yüksekokulu Elektronik Dergisi, 3(1), 30-35.

Dişsiz, M. \& Hotun Şahin, N. (2008). Evrensel bir kadın sağlığı sorunu: Kadına yönelik şiddet. Maltepe Üniversitesi Hemşirelik Bilim ve Sanatı Dergisi, 1(1), 50-58.

Doksat, M. K. (2011). Şiddet psikolojisinin evrimsel yönü. Türkiye Klinikleri, 4(2), 1-7.

Eryılmaz, A. (2012a). Pozitif psikoterapi bağlamında geliştirilen ergenler için amaçları genişletme grup rehberliği programının etkililiğinin incelenmesi. Eğitim ve Bilim, 7(164), 319.

Eryılmaz, A. (2012b). Pozitif psikoterapi bağlamında yaşam amaçları belirleme ölçeğinin üniversite öğrencileri üzerinde psikometrik özelliklerinin incelenmesi. Klinik Psikiyatri, 15, 166-174.

Eşkinat, R. 2013. Türkiye' de kadına yönelik ekonomik şiddet (boşanmış kadınlara yönelik araştırma). Dumlupınar Üniversitesi Sosyal Bilimler Dergisi, 37, 289-302.

Fromm, E. (1994). Sevginin ve şiddetin kaynă̆ı. (Y. Salman ve N. İçten, Çev.). Payel Yayınevi.

Gibbs, A., Jewkes, R., Willan, S. \& Washington, L. (2018). Associations between poverty, mental health and substance use, gender power, and intimate partner violence amongst young (18-30) women and men in urban informal settlements in South Africa: A crosssectional study and structural equation model. PLoS one, 13(10), 1-19. http://doi.org/10.1371/journal.pone.0204956

Gladding, S. T. (2013). Psikolojik danışma, kapsamlı bir meslek. (Çev Ed. N. Voltan-Acar). Nobel Yayın.

Golding, J. M. (1999). Intimate partner violence as a risk factor for mental disorders: a metaanalysis. Journal of Family Violence 14, 99-132. https://doi.org/10.1023/A:1022079418229

Gödelek, K. (2005). Güç iktidar ilişkisi bağlamında kadına yönelik şiddet. Muğla Üniversitesi Sosyal Bilimler Enstitüsü Dergisi, 15, 97-107.

Gregory, A., Feder, G., Taket, A. \& Williamson, E. (2017). Qualitative study to explore the health and well-being impacts on adults providing informal support to female domestic violence survivors. BMJ open, 7 (3), 1-10. http://dx.doi.org/10.1136/bmjopen-2016-014511

Günşen İçli, T. (1994). Aile içi şiddet: Ankara-İstanbul ve İzmir örneği. Hacettepe Üniversitesi Edebiyat Fakültesi Dergisi, 11(1-2), 7-20.

Harnois, G. \& Gabriel, P. (2002). Mental health and work: Iimpact, issues and good practices. World Health Organization and the International Labour Organisation.

Hassan, S. \& Malik, A. A. (2012). Psycho-social correlates of intimate partner violence. Pakistan Journal of Psychological Research, 27(2), 279-295. 
Hogg, A. M. \& Graham M. V. (2011). Sosyal psikoloji. (İ.Yıldız ve A. Gelmez, Çev.). Ütopya Yayınevi.

İncecik, Y., Kurdak, H., Özcan, S., Akpınar, E., Saatçı, E. \& Bozdemir, N. (2009). Eş şiddeti ve aile hekimliği. Turkish Journal of Family Medicine and Primary Care, 3(1), 1-8

James, M. (1994). Domestic violence as a form of child abuse: identification and prevention. Australian Institute of Family Studies.

Jewkes, R., Corboz, J. \& Gibbs, A. (2018). Trauma exposure and IPV experienced by Afghan women: analysis of the baseline of a randomised controlled trial. PLoS one, 13(10), 1-15.

Judge, A. T. \& Bono J. E. (2001). Relationship of core self-evaluations traits self-esteem, generalized self-efficacy, locus of control, and emotional stability with job satisfaction and job performance: A meta-analysis. Journal of Applied Psychology, 86(1), 80-92.

Kadınlara karşı şiddetin tasfiye edilmesine dair bildiri (1993, 20 Aralık). Resmi Gazete, (44/104). https://www.ombudsman.gov.tr/

Kazaura, R. M., Mangi J. E. \& Dereck C. (2016). Magnitude and factors associated with intimate partner violence in mainland Tanzania. BMC Public Healt, 16, 494-501.

Keyes C. L. M. (1998). Social well-being. Social Psychology Quarterly, 61(2), 121-140.

Keyes, C. L. M \& Annas, J. (2009). Feeling good and functioning well: Distinctive concepts in ancient philosophy and contemporary science. The Journal of Positive Psychology, 4(3), 197201.

Keyes, C. L. M., Wissing, M., Potgieter, J. P., Temane, M., Kruger, A. v \& Van Rooy, S. (2008). Evaluation of the mental health continuum-short form (MHC-SF) in Setswana-speaking South Africans. Clinical Psychology and Psychotherapy, 15, 181-192.

Kılıç, B. Ç. (1999). Aile içi kadına yönelik şiddetin belirlenmesi ve hemşirenin rolü. Yüksek lisans tezi, İstanbul Üniversitesi, İstanbul.

Kim, J. \& Gray, K. A. (2008). Leave or stay? Battered women's decision after intimate partner violence. Journal of Interpersonal Violence, 23(10), 1465-1482

Kocacık, F. \& Doğan, O. (2006). Domestic violence against women in Sivas, Turkey: survey study. Croatian Medical Journal, 47(5), 742-749

Kodan Çetinkaya, S. (2013). Üniversite öğrencilerinin şiddet eğilimlerinin ve toplumsal cinsiyet rollerine ilişkin tutumlarının incelenmesi. Nesne Dergisi, 1(2), 21-43.

Kuzgun, Y. \& Sevim, S. (2004). Kadınların çalışmasına karşı tutum ve dini yönelim arasındaki ilişki. Ankara Üniversitesi Ĕ̆gitim Bilimleri Fakültesi Dergisi, 37(1), 14-27. 03

Küçükeskici, B. (2019). Fiziksel şiddetin meşrulaştırılmasının ve toplumsal cinsiyet rollerine ilişkin tutumların evlilikte kadına yönelik fiziksel şiddetin meşrulaştırılması üzerindeki rolünün incelenmesi. Yüksek lisans tezi, Ondokuz Mayıs Üniversitesi, Samsun.

Lerner, C. F. \& Kennedy, L. T. (2000). Stay-leave decision making in battered women: Trauma, coping and self-efficacy. Cognitive Therapy and Research, 24(2), 215-232. 
Lichter, E. L. \& McCloskey, L. A. (2004). The effects of childhood exposure to marital violence on adolescent gender-role beliefs and dating violence. Psychology of Women Quarterly, 28(4), 344-357.

Lüdtke, O., Trautwein, U. \& Husemann, N. (2009). Goal and personality trait development in a transitional period: assessing change and stability in personality development. Personality and Social Psychology Bulletin, 35(4), 428-441.

Machado, C., Martins, C. \& Caridade, S. (2014). Violence in intimate relationships: a comparison between married and dating couples. Journal of Criminology, 2-9. http://dx.doi.org/10.1155/2014/897093

McNaughton-Reyes, H. L. M., Foshee, V. A., Niolon, P. H., Reidy, D. E. \& Hall, J. E. (2016). Gender role attitudes and male adolescent dating violence perpetration: Normative beliefs as moderators. Journal of Youth and Adolescence, 45(2), 350-360.

Mundodan J.M., Lamiya, K.K. \& Haveri, S.P. (2021). Prevalence of spousal violence among married women in a rural area in North Kerala. Journal of Family Medicine and Primary Care, 10(8), 2845-2852.

Nybergh, L., Taft, C., Enander, V. \& Krantz, G. (2013). Self-reported exposure to intimate partner violence among women and men in Sweden: results from a population-based survey. BMC Public Health, 13, 845-858.

O'Brien, K. S., Forrest, W., Greenlees, I., Rhind, D., Jowett, S., Pinsky, I. \& Iqbal, M. (2018). Alcohol consumption, masculinity, and alcohol-related violence and anti-social behaviour in sportspeople. Journal of science and medicine in sport, 21(4), 335-341

Okan-İbiloğlu, A. (2012). Aile içi şiddet. Psikiyatride Güncel Yaklaşımlar, 4(2), 204-222.

Okuda, M.,Olfson, M., Hasin, D., Grant, B.F. Lin, K.H. \& Blanco, C. (2011). Mental health of victims of intimate partner violence: results from a national epidemiologic survey. Psychiatric Services 62, 959-962.

Okyay, P., Atasoylu, G., Önde, M., Dereboy, Ç. \& Beşer, E. (2012). Kadınlarda yaşam kalitesi anksiyete ve depresyon belirtilerinin varlığında nasıl etkileniyor? Kesitsel bir alan çalışması. Türk Psikiyatri Dergisi, 23(3), 178-88.

Orindi, BO., Ziraba, A., Bruyneel, L., Floyd, S. \& Lesaffre, E. (2021). Invariance of the WHO violence against women instrument among Kenyan adolescent girls and young women: Bayesian psychometric modeling. Plos One, 16(10), 1-16.

Özateş, Ö. S. (2009). Bir sosyal hizmet müdahalesi olarak aile içi şiddet mağduru kadın sorununda feminist etik yaklaşım. Toplum ve Sosyal Hizmet, 20(2), 99-107

Özaydın, M. M. \& Özdemir, Ö. (2014). Çalışanların bireysel özelliklerinin iş tatmini üzerindeki etkileri: Bir kamu bankası örneği. İşletme Araştırmaları Dergisi, 6(1), 251-281

Özkazanç, A. \& Yetiş, E. Ö. (2016). Erkeklik ve kadına şiddet sorunu: Eleştirel bir literatür değerlendirmesi. Fe Dergi, 8(2), 13-26.

Polat, O. (2016). Şiddet. Marmara Üniversitesi Hukuk Fakültesi Hukuk Araştırmaları Dergisi, 22(1), 15-34. 
Rada, C. (2014). Violence against women by male partners and against children within the family: prevalence, associated factors, and intergenerational transmission in Romania: A cross-sectional study. BMC Public Health, 14, 1-28.

Rivera-Rivera, L., Lazcano-Ponce, E., Salmerón-Castro, J., Salazar-Martínez, E., Castro, R. \& Hernández-Avila, M. (2004). Prevalence and determinants of male partner violence against Mexican women: A population-based study. Salud Publica Mexico, 46(2), 113-122.

Rosenfield, S. (1989). The effects of women's employment: Personal control and sex differences in mental health. Journal of Health and Social Behavior, 30, 77-91.

Rosenberg, M., Schooler, C., Schoenbach, C. \& Rosenberg, F. (1995). Global self-esteem and specific self-esteem: Different concepts, different outcomes. American Sociological Review, 60(1), 141-156.

Rotter, J.B. (1966) Generalized expectancies for internal versus external control of reinforcement. Psychological Monographs, 80, 1-28.

Rurangirwa, A. A., Mogren, I., Ntaganira, J. \& Krantz, G. (2017). Intimate partner violence among pregnant women in Rwanda, its associated risk factors and relationship to anc services attendance: a population-based study. BMJ Open, 7, 1-11.

Rutherford, A., Zwi, A. B., Grove, N. J. \& Butchart, A. (2007). Violence: a glossary. Journal of Epidemiol Community Health,61,676-680.

Ryff, C. D. (1989). Happiness is everything, or is it? Explorations on the meaning of psychological well-being. Journal of Personality and Social Psychology, 57, 1069-1081.

Sağkal, T., Kalkım, A., Sülü-Uğurlu, E. \& Ersoy-Kırmızılar, N. (2014). Gebelerin eşi tarafından şiddete maruz kalma durumları ve şiddetle ilişkili faktörlerin incelenmesi. TAF Preventive Medicine Bulletin, 13(5), 381-390.

Santana, M. C., Raj, A., Decker, M. R., La Marche, A. \& Silverman, J. G. (2006). Masculine gender roles associated with increased sexual risk and intimate partner violence perpetration among young adult men. Journal of urban health, 83(4), 575-585.

Saygan, B. \& Peken-Uludağll, N. (2021). Yaşam boyu toplumsal cinsiyet rollerinin gelişimi. Psikiyatride Güncel Yaklaşımlar, 13(2),354-382.

Schwartz, S. J., Côté, J. E. \& Arnett, J. J. (2005). Identity and agency in emerging adulthood: Two developmental routes in the individualization process. Youth and Society, 37(2), 201229.

Seçer, Z., Çeliköz, N., \& Yaşa, S. (2007). Bazı kişisel özelliklerine göre okul öncesi eğitim kurumlarına devam eden çocukların babalarının babalığa yönelik tutumları. Selçuk Üniversitesi Sosyal Bilimler Enstitüsü Dergisi, 18, 425-438.

Senemoğlu, N. (2012). Gelişim, öğrenme ve öğretim. Pegem Akademi.

Sorensen, G. \& Verbrugge, L. M. (1987). Women, work, and health. Annual Reviews Public Health, 8, 235-251. 
Su, Z., McDonnell, D., Roth, S., Li, Q. Šegalo, S.,Shi, F. \& Wagers, S. (2021). Mental health solutions for domestic violence victims amid COVID-19: A review of the literature. Globalization and Health, 17(67), 1-11. https://doi.org/10.1186/s12992-021-00710-7

Şen, E. \& Şahin, B. (2021). İstanbul sözleşmesi; Çekilmeli mi, devam m1 etmeli? https://www.hukukihaber.net/istanbul-sozlesmesi-cekilmeli-mi-devam-mietmeli-makale, 8130.html

Tabachnick, B. \& Fidell, L.S. (2015). Çok değişkenli istatistiklerin kullanımı. (M. Baloğlu, Çev.). Nobel.

Tang, S. (2021). Gender-based 'women-to-women' violence against urban Chinese single women (aged 30-48) in contemporary China. Sexuality \& Culture, 25, 1159-1191.

Taşdan, M. \& Erdem, M. (2010). İlköğretim okulu öğretmenlerinin iş yaşamı kalitesi ile örgütsel değer algıları arasındaki ilişki düzeyi. Yüzüncü Yıl Üniversitesi Ĕğitim Fakültesi Dergisi, 7(2), 92-113.

Taycan, O. \& Coşkun, B. (2020). Ruh să̆lığımı güçlendirme kavramlar, kamıtlar, uygulamalar. Türkiye Psikiyatri Derneği Yayınları.

Taylor, S. E., Peplau, L. A. \& Sears, D. O. (2012). Sosyal psikoloji. (Çev. A. Dönmez). İmge.

Tel, H., Kocataş, S., Güler, N., Tel-Aydın, H. \& Akgül-Gündoğdu. N. (2019). Evli kadınların aile içi şiddete maruz kalma durumu ve etkileyen faktörler. IBAD Sosyal Bilimler Dergisi, (Özel Sayl), 256-264.

Thomas, L. J., Lewis, J. B., Martinez, I., Cunningham, S. D., Siddique, M., Tobin, J. N. \& Ickovics J. R. (2019). Associations between intimate partner violence profiles and mental health among low-income, urban pregnant adolescents. BMC Pregnancy and Childbirth, 19(1), 120128.

Tun, T. \& Ostergren, P. O. (2020). Spousal violence against women and its association with sociodemographic factors and husbands' controlling behaviour: the findings of Myanmar Demographic and Health Survey (2015-2016). Global Health Action, 13, 1-12.

Turan, N. (2018). Çalışma mutluluğu: Kavram ve kapsam. B.U.Ü. İktisadi ve İdari Bilimler Fakültesi Dergisi, 37(1), 169-212.

TÜİK (Türkiye İstatistik Kurumu) [04.04.2020]. Türkiye'de kadına yönelik aile içi şiddet araştırması. http://www.tuik.gov.tr/MicroVeri/KYAS_2014/downloads/agiirliik.xlsx

Türk, H. B. (2008). Eril tahakkümü yeniden düşünmek: erkeklik çalışmaları için bir imkân olarak pierre bourdieu. Toplum ve Bilim, 112, 119-146.

Uçar, O. (2011). İzmir aile mahkemelerinde boşanma davası görülen kadınların eş şiddetine maruz kalma durumu.Yüksek lisans tezi, Dokuz Eylül Üniversitesi, İzmir.

Ünal, B. \& Gülseren, L. (2020). COVID-19 pandemisinin görünmeyen yüzü: Aile içi kadına yönelik şiddet. Klinik Psikiyatri Dergisi, 23(Ek 1), 89-94.

Vameghi, R., Akbari, S. A. A., Majd, H. A., Sajedi, F. ve Sajjadi, H. (2018). The comparison of socioeconomic status, perceived social support and mental status in women of 
reproductive age experiencing and not experiencing domestic violence in Iran. Journal of Injury and Violence Research, 10(1), 35-44.

Vefikuluçay-Yılmaz, D., Zeyneloğlu, S., Kocaöz, S., Kısa, S., Taşkın, L. \& Eroğlu, K. (2009). Üniversite öğrencilerinin toplumsal cinsiyet rollerine ilişkin görüşleri. Uluslararası İnsan Bilimleri Dergisi, 1(6), 775-792.

Visser, M. M., Telman, M.D., Schipper, J. C., Lamers, F., Schuengel, W. C. \& Finkenauer, C. (2015). The effects of parental components in a trauma-focused cognitive behavioral based therapy for children exposed to interparental violence: Study protocol for a randomized controlled trial. BMC Psychiatry, 15, 1-18.

Walby, S. \& Towers, J. S. (2017). Measuring violence to end violence: Mainstreaming gender. Journal of Gender-Based Violence, 1(1), 11-31.

World Health Organization. [14.04.2019]. Definition and typology of violence. https://www.who.int/violenceprevention/approach/definition/en/

Yanıkkerem, E. (2002). 15-49 yaş evli kadınların aile içi şiddete ilişkin görüşlerinin ve şiddete maruz kalma durumlarının incelenmesi. Yüksek lisans tezi, Ege Üniversitesi, İzmir.

Yaşar, M. R. (2017). İki şiddet arasında kadın. Akademik Matbuat, 1(1), 1-20.

Yüksel-Şahin, F. \& Taşkın, T. (2019). Çalışmayan ev kadınlarının mutluluk ve kişisel gelişim yönelimi düzeylerinin incelenmesi. Eğitimde Kuram ve Uygulama, 15(Özel Sayı 1), 24-36.

Zeyneloğlu, S. (2008). Ankara'da hemşirelik öğrenimi gören üniversite öğrencilerinin toplumsal cinsiyet rollerine ilişkin tutumları. Doktora tezi, Hacettepe Üniversitesi, Ankara. 